\title{
Glacier Peak - History and Hazards of a Cascade Volcano
}

lacier Peak is the most
remote of the five active
volcanoes in Washington
State. It is not prominently
visible from any major popu-
lation center, and so its
attractions, as well as its
hazards, tend to be over-
looked. Yet since the end of
the last ice age, Glacier Peak
has produced some of the
largest and most explosive
eruptions in the state. During
this time period, Glacier Peak
has erupted multiple times
during at least six separate
episodes, most recently
about 300 years ago. What
were these eruptions like?
Could similar ones affect us
today? Scientists from the
U.S. Geological Survey
lUSGS) are working to
answer these questions and
help prepare for future
activity.

The stunning snow-capped volcanoes of Washington State have long been recognized by Native Americans in their language and legends, and they immediately caught the eyes of U.S. and European explorers in the late 18th and early 19 th centuries. By the 1790 's, Mounts Baker, Rainier, and St. Helens were noted and named in the first written descriptions of the Columbia River and Puget Sound regions. In 1805 Lewis and Clark noted Mount Adams. By the mid-19th century each of these four volcanoes had their place on a published map.

Glacier Peak wasn't known by settlers to be a volcano until the 1850 's, when Native Americans mentioned to naturalist George Gibbs that "another smaller peak to the north of Mount Rainier once smoked." Not until 1898 did Glacier Peak appear on a published map under its current name.

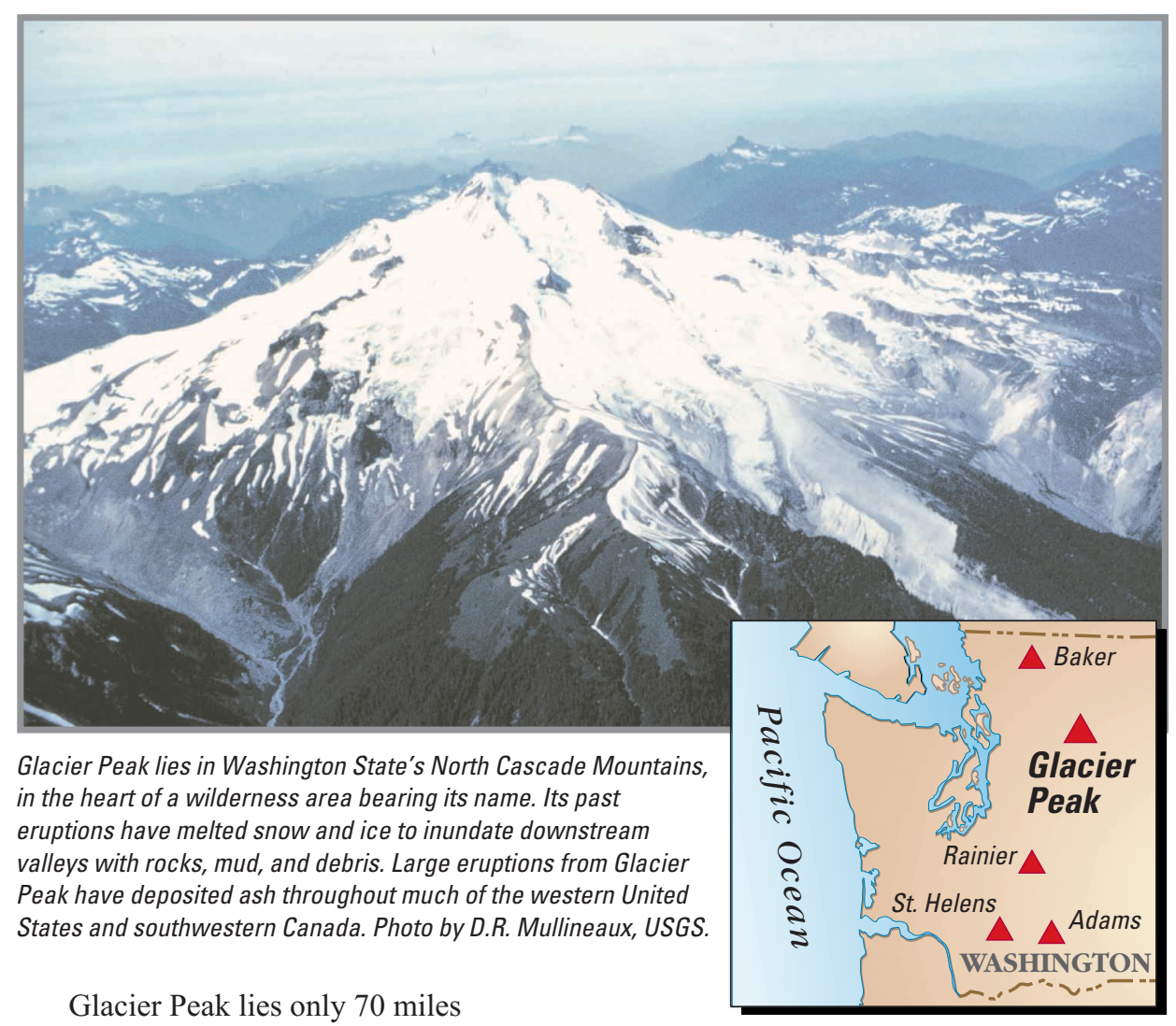

northeast of Seattle - closer to that city than any volcano except Mount Rainier. But unlike Mount Rainier, it rises only a few thousand feet above neighboring peaks, and from coastal communities it appears merely as a high point along a snowy saw-toothed skyline. Yet Glacier Peak has been one of the most active and explosive of Washington's volcanoes.

\section{Glacier Peak's eruption history}

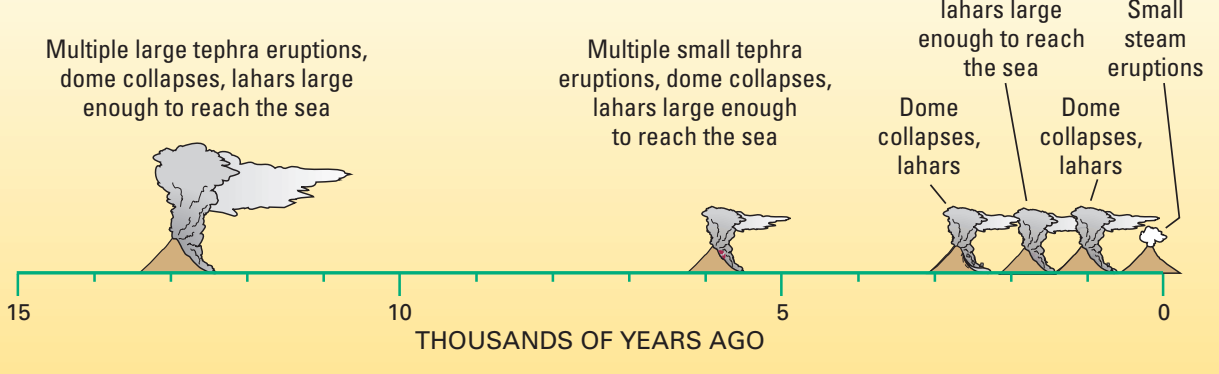

Known eruptive episodes at Glacier Peak during the past 15,000 years. Each episode (depicted by a single icon) represents many individual eruptions. The ages of these episodes, in calendar years before present are corrected from dates based on a radiocarbon time scale. The uncorrected radiocarbon ages for these episodes, which appear in some publications, are 11,200, 5,100, 2,800, 1,800, 1,100, and 300 years before present.
Since the continental ice sheets receded from the region, Glacier Peak has erupted repeatedly during at least six episodes. Two of these eruptions were among the largest in Washington during the past 15,000 years. These pages describe some of the effects of past eruptions and possible consequences of future activity. 


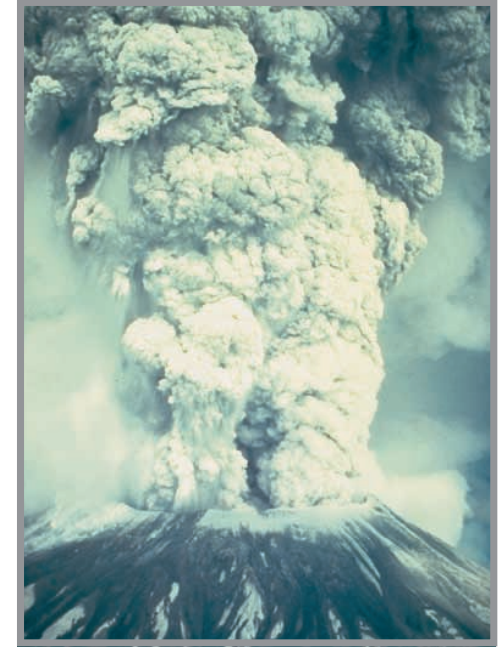

Eruption column from Mount St. Helens on May 18, 1980. Rock fragments (tephra) give the column the gray color. Tephra from the eruption fell as far away as Colorado. About 13,100 years ago, an explosive eruption from Glacier Peak generated a sequence of tephra eruptions, the largest of which ejected more than five times as much tephra as the May 18,1980 eruption of Mount St. Helens. Photo by Austin Post, USGS.

\section{During Past Eruptions . . .}

\section{Tephra Covered the Landscape}

Glacier Peak and Mount St. Helens are the only volcanoes in Washington State that have generated large, explosive eruptions in the past 15,000 years. Their violent behavior results from the type of molten rock (magma) they produce. Dacite, the typical magma type of Mount St. Helens and Glacier Peak, is too viscous to flow easily out of the eruptive vent; it must be pressed out under high pressure. As it approaches the surface, expanding gas bubbles within the magma burst and break it into countless fragments. These fragments are

collectively known as tephra; the smallest are called ash.

About 13,100 years ago, Glacier Peak generated a sequence of nine tephra eruptions within a period of less than a few hundred years. The largest ejected more than five times as much tephra as the May 18, 1980, eruption of Mount St. Helens and was one of the largest in the Cascade Range since the end of the last ice age.

Some of the tephra from these eruptions fell back onto the volcano and avalanched down its flanks. Much of the rest rose high into the atmosphere and drifted hundreds to thousands of miles downwind. Deposits from these eruptions are more than a foot thick near Chelan, Washington, and an inch thick in western Montana.

Since these events, Glacier Peak has produced several tephra eruptions, all of much smaller volume.

\section{Lava Domes Collapsed onto the Volcano's Flanks}

During most of Glacier Peak's eruptive episodes, lava domes have extruded onto the volcano's summit or steep flanks. Parts of these domes collapsed repeatedly to produce pyroclastic flows and ash clouds. The remnants of prehistoric lava domes make up Glacier Peak's main summit as well as its "false summit" known as Disappointment Peak. Pyroclastic-flow deposits cover the valley floors east and west of the volcano.

Ridges east of the summit are mantled by deposits from ash clouds.

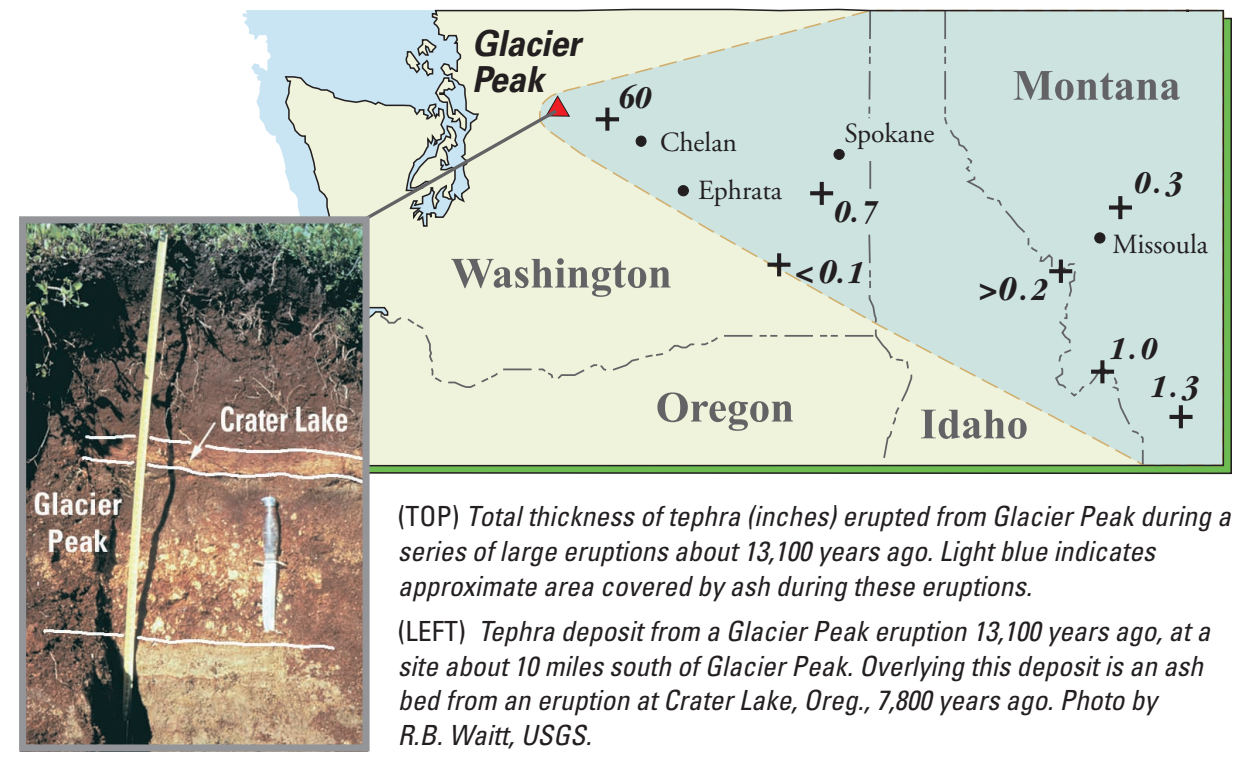

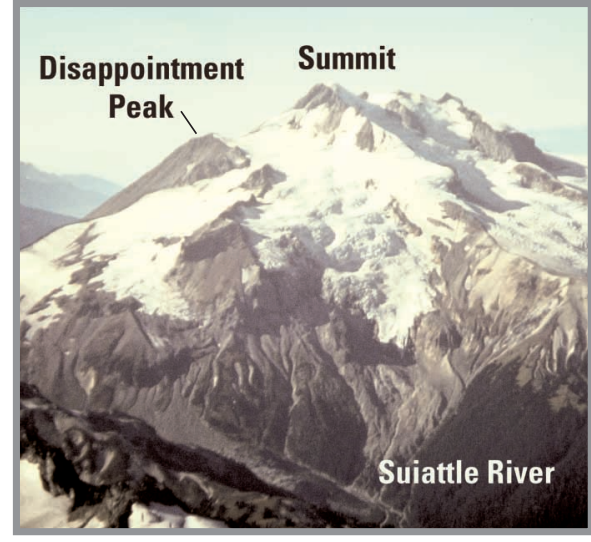

Glacier Peak from the east, showing the main summit and Disappointment Peak, which are remnants of prehistoric lava domes. Photo by Austin Post, USGS.

\section{Lahars Inundated River Valleys}

Past eruptions have severely affected river valleys that head on Glacier Peak. Pyroclastic flows mixed with melted snow and glacial ice to form rapidly flowing slurries of rock and mud known as lahars.

About 13,100 years ago, dozens of eruption-generated lahars churned down

\section{How do lava domes collapse and generate pyroclastic flows?}

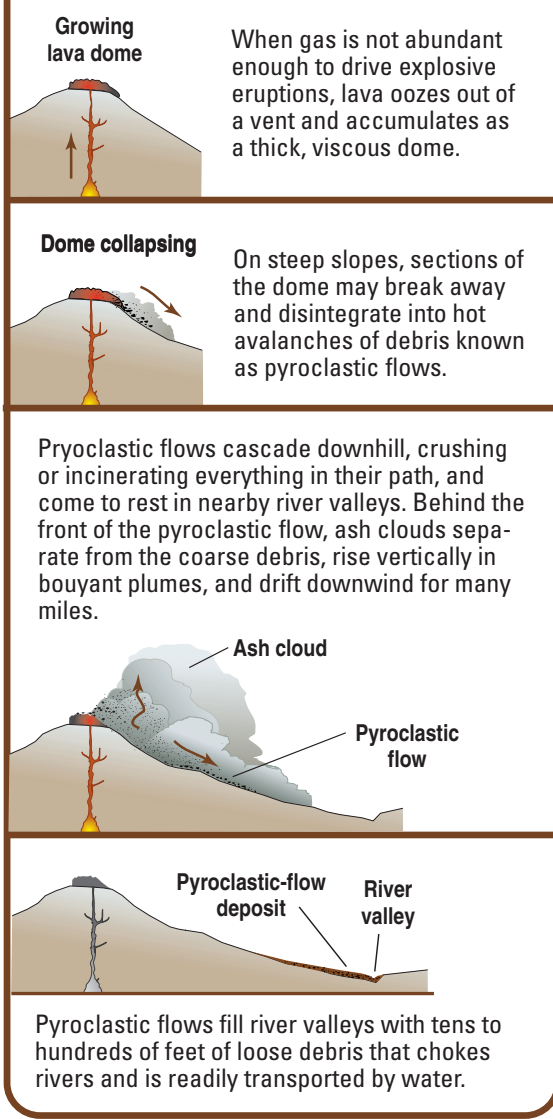




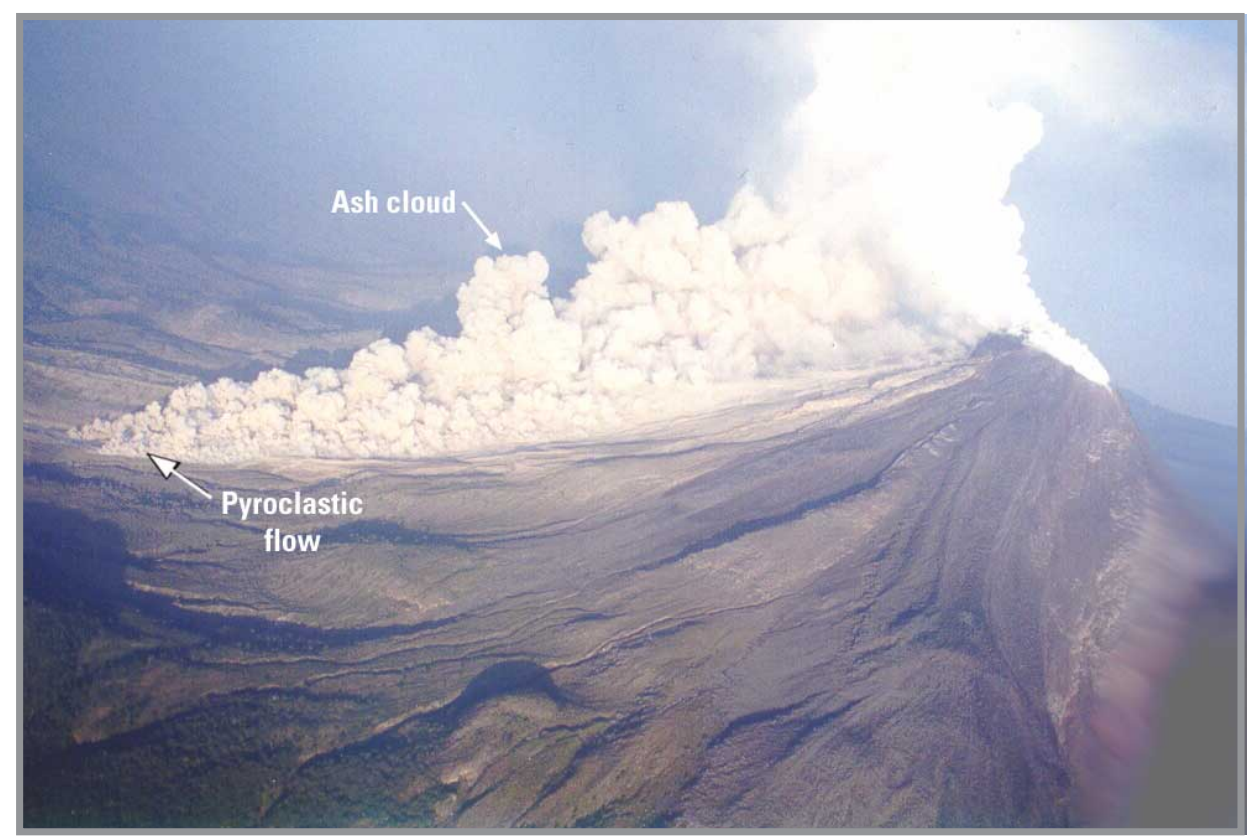

A collapsing lava dome generates a pyroclastic flow and ash cloud at Colima Volcano, Mexico, November 22, 1998. Photo by Abel Cortes, (C)1998, University of Colima.

the White Chuck, Suiattle, and Sauk Rivers, inundating valley floors. Lahars then flowed down both the North Fork Stillaguamish (then an outlet of the upper Sauk River) and Skagit Rivers to the sea. In the Stillaguamish River valley at Arlington, more than 60 miles downstream from Glacier Peak, lahars deposited more than seven feet of sediment. Shortly after the eruptions ended, the upper Sauk's course via the Stillaguamish was abandoned and the Sauk River began to drain only into the Skagit River, as it does today.

About 5,900 years ago and 1,800 years ago, dome-building eruptions generated lahars that extended once again to the sea, this time only along the Skagit River. In small eruptions since 1,800 years ago, lahars have extended the entire length of the White Chuck River and part way down the Suiattle.

Lahars can also be generated by landslides (also called flank collapses) on volcanoes, as has happened repeatedly at Glacier Peak's neighbor to the north, Mount Baker. At Mount Baker, lahars from numerous landslides, some without accompanying eruptive activity, have affected valley floors near the volcano. A few much larger landslides during eruptive periods generated lahars that flowed hundreds of feet deep through upper valleys and reached the sea. At Glacier Peak landslide-generated lahars have occurred less frequently than at Mount Baker.

\section{During Future Eruptions . . .}

Glacier Peak's eruptive episodes are typically separated by several hundred to a few thousand years. Thus in any given year, the probability of a new episode beginning is roughly one in a thousand. It is unlikely that we will see an eruption within our lifetimes. If one does take place, its impact would vary dramatically in different geographic areas depending on the size of the eruption, wind direction, and type of hazards produced.

In undeveloped areas near the volcano, the landscape would be severely altered by lava domes, pyroclastic flows, ash clouds, lahars, and associated phenomena.
In river valleys downstream from the volcano, lahars could block transportation routes, destroy highways and bridges, bury houses in mud, cover farmland with debris, choke river channels, and increase the severity of floods for years or decades after the eruptions stop. These effects will be most frequent in the White Chuck and upper Suiattle River valleys. They will be less frequent, but potentially more damaging due to greater population and infrastructure, in the Sauk and Skagit River valleys. Still less likely would be lahars in the Stillaguamish River valley, which would occur only if the Sauk River became choked with enough debris to be diverted west into the Stillaguamish River valley. When a lahar takes place, residents of communities along these rivers should move to high ground as quickly as possible.

In areas downwind from the volcano, even small tephra eruptions could disrupt air and ground transportation and dust towns with ash. Tephra could clog drainage ducts and ventilation filters, short-circuit power transformers, damage machinery and electronic equipment, reduce visibility, exacerbate respiratory ailments, and stall transportation. Large tephra eruptions (comparable to Glacier Peak's largest) would have more widespread effects and could deposit enough tephra to collapse roofs in nearby downwind communities. Owing to prevailing wind patterns, tephra fall during future eruptions is most likely east of Glacier Peak. But tephra could affect communities in all directions from the volcano depending on wind patterns during an eruption. Five tephra eruptions from Mount

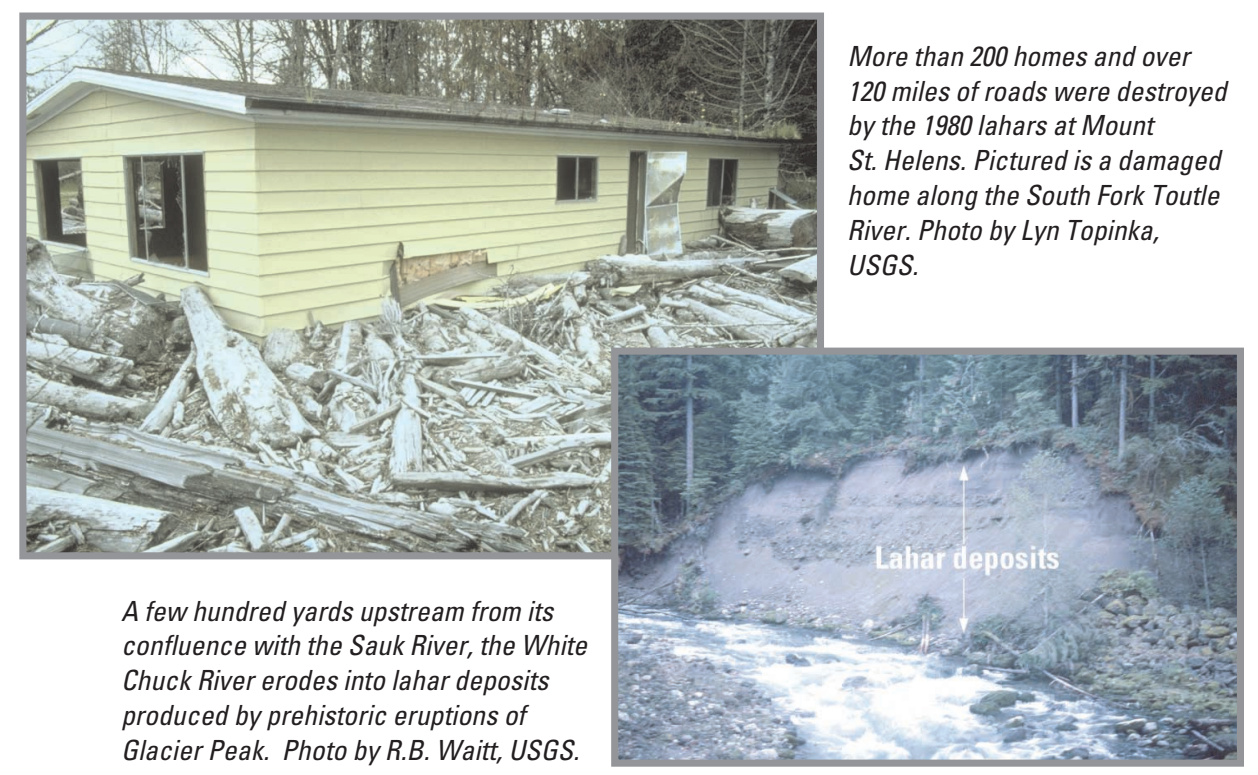




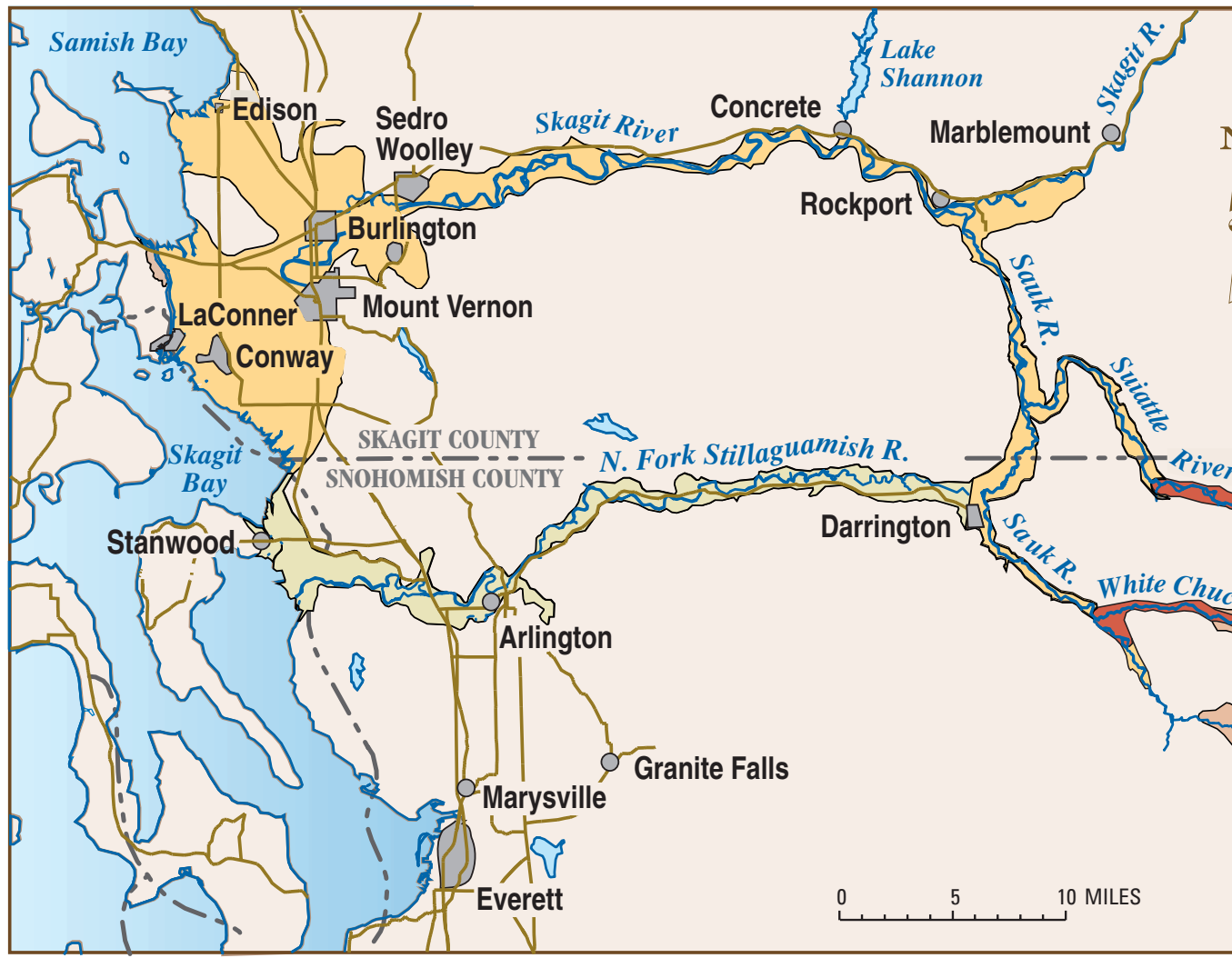

Areas at risk from lahars, lava domes, pyroclastic flows, and associated phenomena from Glacier Peak. Map modified from R.B. Waitt and others, U.S. Geological Survey Open-File Report 95-499.

St. Helens in 1980, for example, deposited ash north, east, west, and south of the volcano. Damage from tephra can be mitigated by such actions as shutting down and covering equipment, frequently replacing air filters in machinery, wearing dust masks, and avoiding unnecessary travel.

\section{Preparing for the Next Eruption}

Future eruptions from Glacier Peak will almost certainly be preceded by an increase in earthquake activity, and possibly by measurable swelling of the volcano and emission of volcanic gases. In cooperation with the USGS, the University of Washington's Geophysics Program continuously monitors earthquakes that could portend Glacier Peak's next eruption. The USGS also works with Federal, State, Provincial, and local agencies to prepare for disruption that might accompany renewed activity. A coalition of these agencies, known as the Mount Baker-Glacier Peak Facilitating Committee, has drafted a plan outlining how agencies will work together in the event of unrest at Mount Baker or Glacier Peak. If Glacier Peak were to reawaken, the USGS would rapidly deploy additional monitoring instruments and, together with these agencies, establish a local volcano observatory and command center that would keep nearby communities informed of developments.

\section{What You Can Do}

- Learn about the volcano hazards that could affect your community, and determine whether you live, work, play, or go to school in a volcanohazard zone.

- Plan what you and your family will do if a hazardous volcanic event occurs.

- Participate in helping your community be prepared.

A few moments spent now could help prevent the next eruption from becoming a disaster for you, your family, and your community.

\section{Larry Mastin and Richard Waitt}

Graphics and design by

Christine Janda, Bobbie Myers, and Lisa Faust

COOPERATING ORGANIZATIONS

U.S. Department of Agriculture, Forest Service University of Washington, Geophysics Program
EXPLANATION

Pyroclastic flows, flank collapses, and associated phenomena

LAHARS

More frequent

Less frequent

Least frequent

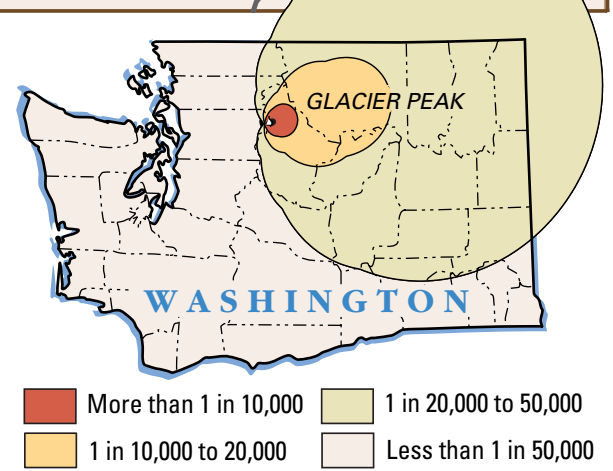

Annual probability of tephra fall exceeding 0.5 inch thick from an eruption of Glacier Peak. Communities east of the volcano are more susceptible to tephra fall because the wind is normally from the west. Glacier Peak has produced large tephra eruptions, but not frequently.

For more information contact: U.S. Geological Survey Cascades Volcano Observatory 5400 MacArthur Blvd., Vancouver, WA 98661

Tel: (360) 993-8900, FAX: (360) 993-8980 http://vulcan.wr.usgs.gov/ or

USGS Volcano Hazards Program http://volcanoes.usgs.gov/ or

your local emergency management agency: Skagit County (360) 428-3250

Snohomish County (425) 423-7635

See also Volcanic-Hazard Zonation for Glacier Peak Volcano, Washington (USGS Open-File Report 95-499) and What are Volcano Hazards? (USGS Fact Sheet 002-97) 